\title{
ECONOMIA SOLIDÁRIA, A PERSPECTIVA EUROPÉIA
}

Jean-Louis Laville

Resumo. Na Europa, é bem verdade, o reconhecimento dos direitos humanos desestabilizou a antiga ordem social sem eliminar as diferenças de condições herdadas das sociedades tradicionais. Com o surgimento da questão social, desde o século XIX, a compatibilidade entre cidadania e desenvolvimento econômico teve como resultado ser o objeto de debates apaixonados, nos quais se inscreveram as associações emergentes. O objetivo desta contribuição é salientar a existência de um número significativo de pesquisas sobre o associativismo os quais demarcam perspectivas hipotético-dedutivas próprias da teoria econômica padronizada, tendo como recurso metodologias mais históricas e compreensivas. Seus principais resultados nos levam a relativizar as noções de não-lucratividade e de terceiro setor. É principalmente o conceito de solidariedade que aparece como essencial para se explicitar as diversas práticas sociais que podem estar reagrupadas pelo nome genérico de associativismo cívico.

Palavras-chave: economia solidária, cooperativa, associação de ajuda mútua.

\section{A solidariedade, uma referência polissêmica}

É nessa articulação entre criação associativa e referência à cidadania que reside, ao menos em parte, a explicação do recurso a terminologia da solidariedade. Mas o consenso em evocar o termo solidariedade (Vincent, 1997, p. 365) nos remete efetivamente a duas 
formas distintas de solidariedade, co-presentes desde a origem das associações modernas e sobre as quais a Inglaterra e a França surgem como dois casos emblemáticos.

\section{A solidariedade filantrópica}

No Reino Unido, no século XIX, a idéia de um órgão caritativo foi associada à discussão sobre a cidadania. A caridade tinha sido apreendida como um princípio social, um elemento necessário para a sociedade democrática contribuindo para sua regulação pela via da moralidade, o engajamento voluntário altruísta. Os governos vitorianos tinham como objetivo "fornecer um quadro de regras e de diretrizes concebidas para permitir a sociedade de se autogestionar em larga medida", daí a forte autonomia dada para as associações e suas atividades de benfeitoria que não eram financiadas pelo Estado, ao mesmo tempo que uma cooperação com a administração encarregada da lei sobre os pobres. Aliás, uma grande parte das prestações sociais públicas eram financiadas e geradas localmente, a limitação do governo central gerando um conjunto de "instituições intermediárias" desenvolvidas entre o Estado e o cidadão que faziam "parte integrante do tecido do Estado" (Lewis, 1997, p. 169).

Ao final do século XIX, é provável que as associações canalizassem tanto dinheiro quanto os serviços encarregados da aplicação da lei sobre os pobres. É, sem dúvida, nenhuma o caso se incluirmos as obras caritativas de auxilio médico (medical charities). Na época, esse fenômeno surpreendeu os pesquisadores franceses, que calcularam que uma grande parte dos adultos britânicos eram filiados a cinco ou seis órgãos associativos em média. Essa lista contava com sindicatos e sociedades mutuelles de previdência (friendly societies) que detinham ambos um papel fundamental na proteção financeira de seus membros em caso de doença ou desemprego, sociedades de seguros de diferentes tipos e, por fim institutos literários e científicos...

$\mathrm{Na}$ virada do século, o debate sobre os órgãos caritativos era associado à discussão sobre a cidadania. Alguns dos dirigentes mais influentes da esfera caritativa estimavam que a caridade constituía um princípio de vida em sociedade. As empresas caritativas representavam cidadãos unidos por uma via moral e preenchendo de forma voluntária seus deveres para com aqueles que tinham menos oportunidades. A idéia 
era a de que as pessoas mais favorecidas fizessem por si só seus deveres de cidadão e ajudassem os pobres a participarem plenamente da sociedade. A injunção de se comportar solidariamente equivalia, portanto, a uma visão específica de uma sociedade ética, na qual os cidadãos motivados pelo altruísmo preenchiam seus deveres uns para com os outros sobre uma base voluntária. A importância atribuída à participação em uma ação voluntária, considerada como um elemento necessário à sociedade democrática, em seguida permaneceu. Durante os anos 1940, foram estabelecidas comparações nesse sentido entre "o sistema britânico e o nazista" (Lewis, 1997, p. 167-168).

Essa dinâmica do interesse geral (Gui, 1993) ou de ajuda a outrem é portanto uma fonte da ação associativa que foi determinada desde o século dezenove. Se tentarmos utilizar esse desvio histórico para esclarecer aquilo que está em jogo no presente, essa "conceitualização da caridade como um principio social" (Lewis, 1997, p. 169) sofre, hoje mais do que ontem, do "descrédito ritualístico da caridade" que obriga os atores sociais a "recorrer unicamente ao vocábulo da solidariedade, investindo-o assim de conotações derivadas de seu outro, a caridade" (Vincent, 1997, p. 370). Levar em conta a história das associações no Reino Unido revela, portanto, a importância que reveste uma concepção da solidariedade "uma preocupação que para os liberais é secundária" (idem). Focalizada sobre a "questão da urgência" e da preservação da paz social, ela tem por objetivo aliviar os pobres e moralizá-los através da prática de ações filantrópicas paliativas. Ela é, assim, baseada no apelo à responsabilidade pessoal. Através de seu engajamento, os indivíduos, pessoas físicas, as empresas e pessoas morais estão na medida de contribuir para a coesão social organizando apoio aos membros mais desfavorecidos da sociedade. Relações sociais dissimétricas são, portanto, validadas entre as pessoas que se engajam desse modo e os beneficiários de sua solicitude. Nessa versão, a solidariedade surge de uma disposição moral estimulando o engajamento voluntário pela defesa dos mais desmunidos. São as convicções e os valores privados que devem ser mobilizados para corrigir as desigualdades sociais.

Essa acepção da solidariedade, não diz respeito a uma característica insular, ela existe em diferentes graus em todos os países da Europa Continental. Não menos importante, é o fato de ter marcado 
particularmente as representações anglo-saxônicas de associações como atestam as freqüentes assimilações entre ações benevolentes e filantrópicas. Esta pré-disposição a ajudar outrem, valorizada como um elemento constitutivo da cidadania responsável, trás consigo a ameaça de um "dar sem reciprocidade" (Ranci, 1990), tendo como único resultado uma gratidão sem limites, criando assim uma dívida que jamais poderá ser honrada pelos beneficiários. Os laços de dependência pessoal que ela favorece correm o risco de aprisionar os beneficiários em sua situação de inferioridade.

Dito de outra forma, ela carrega em si um dispositivo de hierarquização social e de manutenção das desigualdades que se apoia nas redes sociais de proximidade que podem se expressar através das escolhas aparentemente salvadoras como aquelas que colocam as associações dentro de organizações privadas. Uma tal classificação tem como objetivo salientar a autonomia de decisões dessas estruturas, mas pode igualmente induzir que esses espaços privados emanem apenas de seus promotores e englobem somente eles: em outras palavras, é a dimensão do espaço público próprio das associações que, nesse caso, é ignorada. Uma tal aproximação os reduz a uma crítica e a uma deliberação envolvendo outras pessoas que não seus membros. Em testemunho estão os trabalhos de Donati (1996) que define a associação como o "privado social". Eles evidenciam o quanto a visão filantrópica não é a emanação de um universo cultural especificamente anglo-saxão, mas sim, uma posição recorrente nas discussões sobre a natureza das associações. O "dar" não é submetido a outras leis coletivas que aquelas emitidas pelos donatários susceptíveis de estabilizar as condições do exercício, assim ele pode se converter em instrumento de poder e de dominação.

\section{A solidariedade democrática}

A esta versão "beneficiente", se opõe uma versão da solidariedade como princípio de democratização da sociedade resultante de ações coletivas, supondo uma igualdade de direito entre aqueles que se engajam. Esta segunda versão moldou a realidade francesa, marcada tanto pelo igualitarismo como pela força das noções de vontade geral e de interesse geral. Logo após a Revolução, toda coalizão de interesses 
tinha sido proibida e os corpos intermediários denunciados pelo fato de que poderiam interferir na relação entre o cidadão e o Estado. Mas, depois que a esperança segundo a qual a instauração da liberdade civil poderia bastar para gerar uma tendência em direção a igualdade de condições se viu fracassada, foi em nome da solidariedade que se moldaram as associações trabalhistas entre 1830 e 1848 (Chanial, 2000). Finalmente, é a afirmação desse princípio de solidariedade que progressivamente, permitirá ultrapassar a alternativa entre liberalismo e poder estatal. Duas concepções de solidariedade se afirmaram no século XIX: a de solidariedade como vínculo social democrático de Leroux, e a de solidariedade como dívida social dos solidários.

É com a preocupação de pensar o vinculo social moderno além do liberalismo, que Pierre Leroux (1841, p. 378) elabora a noção de solidariedade: "A natureza humana não criou um só ser para si mesmo... ela os criou uns para os outros, e colocou entre eles uma solidariedade recíproca". Em detrimento de certos pontos datados dessa teleologia política, o importante é reter a forte crítica tanto da caridade quanto das teorias do contrato social ou de uma visão organicista da sociedade. Para escapar tanto de um individualismo concorrencial como de um estatismo autoritário, Leroux insiste sobre o estabelecimento de uma comunicação entre o Estado e a sociedade que pretende ter grupos intermediários, isso conduz a preconizar que corporações assumam um papel de instituição pública. Leroux estabelece metodicamente sobre redes de solidariedade passando pelo "atelier", como em associações o entretenimento do espirito público indispensável à democracia. Seu pensamento está em ressonância com os movimentos da época. Ele faz eco a um associativismo operário dentro do qual ele intervém já que, o sujeito se engaja justamente à procura de uma economia que poderia ser solidária: a organização do trabalho que fica á encontrar poderia fornecer a oportunidade de organizar entidades produtivas que inscrevem a solidariedade no coração da economia. Esse projeto de uma economia solidária ou fraternal é simbolizado pelo momento de 1848, onde ele atinge seu apogeu antes de encontrar seu refluxo.

Depois do traumatismo de 1848 , onde a repressão sanciona a palavra operária, é no final do século XIX que a noção de solidariedade surge como meio para os republicanos de estabelecer uma terceira via entre o liberalismo e o socialismo que reconcilia os direitos individuais 
e a responsabilidade do Estado. Defendida por homens políticos, juristas ou sociólogos que se reclamam do solidarismo (Bouglé, Bourgeois, Duguit, Durkheim...), a noção de solidariedade toma um novo sentido. Mais que por participação comum à humanidade, como em Leroux, os solidaristas falam de dívida social para com as gerações passadas que fazem os homens devedores para com as gerações seguintes: o que implica num quase contrato, "forma jurídica de dupla dívida social correspondendo ao dever de solidariedade em relação aos nossos semelhantes e em relação aos nossos descendentes" (Dubois, 1985, p. 58). Como o indica Bourgeois (1992, p. 22-23), "o dever social não é uma simples obrigação de consciência, é uma obrigação fundada no direito, não podemos nos cegar frente a sua execução sem violar uma regra precisa da justiça", e o Estado pode impor essa regra "a necessidade pela força" afim de assegurar "a cada um sua parte legitima no trabalho e nos produtos'. A procura de equilíbrio entre liberdade e igualdade se constrói por dissociação e complementaridade entre o econômico e o social que encontram sua formulação na "idéia de serviço publico amarrada com a noção de solidariedade". O Estado, expressão da vontade geral, torna-se depositário desta vontade que ele pode por em execução graças a ações da administração. A administração, que mantém sua legitimidade pela representação política assim como a empresa mantém sua legitimidade pelo capital, só pode ver no usuário um devedor submisso para quem prestações são distribuídas num movimento descendente, do Estado em direção aos administrados, que sozinho pode garantir o respeito pelo interesse comum. A legitimidade da intervenção do Estado é limitada pela solidariedade social, mas ela reforça "sua potência tutelar" e "seu papel central quanto à forma da sociedade" (Lafore, 1992, p. 261-263). "O Estado não é mais somente potência soberana, poder de reprimir"; ele torna-se "segurança mútua e a relação social se molda sobre a mutualidade" (Ewald, 1986, p. 344). Baseada no direito, a intervenção do Estado destinada aos cidadãos-assalariados submissos impõe-se como uma adaptação pragmática das teorizações da coesão social preocupada em evitar o duplo perigo do "individualismo" e do "coletivismo".

Em suma, as duas correntes portadoras do conceito de solidariedade operaram como uma ruptura em relação ao imaginário liberal. É inclusive o motivo pelo qual a solidariedade está ligada à emergência da Sociologia, como proposta de um paradigma alternativo 
ao individualismo contratualista. Essa concepção, segundo a qual a sociedade moderna se resumiria no contrato, se ela está amplamente presente na história francesa, também não constitui uma exceção; em vários outros contextos nacionais esta cultura da ajuda mútua e da autoorganização marcou duramente o fenômeno associativo.

\section{Da gênese ao processo de institucionalização}

Resumindo, desde o início do século XIX, dinâmicas associacionistas emergiram nas democracias modernas, fazendo apelo a um conceito amplo e polissêmico de solidariedade que engloba filantropia e ajuda mútua. Essas ações foram progressivamente reconhecidas pelos poderes públicos e resultaram na elaboração de quadros jurídicos que, ao mesmo tempo, davam-lhes uma existência legal e contribuíam para separar aquilo que o domínio associacionista original pretendia reunir. Os status das cooperativas, das mutuelles e das associações são adotados ao mesmo tempo que são distinguidos. Por outro lado, as diferentes disposições jurídicas que regem as associações contém limites que vão bloquear as organizações na sua relação com a atividade econômica: na Itália, as associações produtoras dos mais importantes serviços sociais foram obrigadas a se transformarem em agências públicas na virada do século XX; na França, a capacidade de ação econômica das associações está ligada ao seu controle pelo Estado, preocupado em não permitir que a Igreja consolide seu poder; no Reino Unido, os critérios que definem as charities introduzem uma discriminação negativa em relação às ações de ajuda mútua e restringem os campos de ação aos domínios filantrópicos tradicionais; na Suécia as ideell association, características da auto-organização, são diferenciadas das associações econômicas.

\section{A autonomização das cooperativas e das mutuelles}

Muitas atividades econômicas concebidas no miolo associativo se abrigam nas estruturas cooperativistas ou mutualistas, menos bloqueadas em sua dimensão produtiva. Deste modo, a partir do final do século XIX e no decorrer do século XX, a explosão e a fragmentação (Vienney, 1994, p. 76-83) se acentuaram sobre o efeito das separações jurídicas e das formas de integração no sistema econômico, que 
conduzem a distinguir três subconjuntos correspondentes aos três status jurídicos obtidos: cooperativo, mutualista e associativo. Do mais, cada um desses subconjuntos torna-se tributário do modelo de desenvolvimento econômico e social no qual ele se insere, em particular na separação que se instaura e se reforça entre economia de mercado e Estado social. Na circunstância, o impulso associacionista que havia constituído a primeira reação da sociedade contra as desregulamentações ocasionadas pela difusão do mercado cede, progressivamente, lugar à intervenção do Estado. O Estado elabora um modo específico de organização, o social, que torna praticável a extensão da economia de mercado conciliando-a com a cidadania dos trabalhadores. Tendo em vista o lugar atribuído à economia de mercado, as fraturas introduzidas por ela devem ser corrigidas pela intervenção reparadora de um Estado protetor, daí a concepção de um direito social composto por um direito trabalhista na empresa e de uma proteção social destinada a preveni-los contra os principais riscos. A questão social desemboca na separação do econômico, na sua aceitação de economia de mercado, e do social, modo jurídico de proteção da sociedade que se elabora a partir do trabalho nos dois registros ligados ao direito trabalhista e à proteção social.

Nesse quadro, uma intervenção pública aparece menos como uma ameaça para a economia de mercado do que como complemento. Logo após a Segunda Guerra Mundial, sob a necessidade de estabelecer consensos nacionais, é que essa complementaridade entre Estado e mercado toma toda sua importância. O Estado keynesienista se dá por obrigação o favorecimento do desenvolvimento econômico através de novos utensílios de conhecimento e de intervenção. Paralelamente, o Estado-Providência estende suas formas precedentes de Estado social com a seguridade e a generalização de sistemas de proteção social. Através de seus novos papéis, o Estado enquadra e sustenta o mercado tanto quanto corrige as desigualdades. A sinergia entre Estado e mercado, manifesta-se em particular pela difusão do status salarial, graças a um fluxo regular de criações de emprego e graças a ganhos de alta produtividade permitindo negociações salariais periódicas. O status salarial realiza um acoplamento inédito entre trabalho e proteções que o faz um vetor privilegiado de integração social. No seio deste modo de desenvolvimento, cooperativas e mutuelles sofrem pressões do meio que se traduzem em fenômenos de isomorfia institucional, ou seja, "processos constrangedores que obrigam as unidades de uma população 
a parecer com outras unidades que se confrontam com as mesmas dificuldades" (Di Maggio e Powell, 1983, p. 150). Este isomorfismo mercadológico para as cooperativas e não para as mutuelles, faz com que essas entidades sejam "tocadas pela banalização de seu comportamento econômico" (Vivet e Thiry, 2000).

As cooperativas se inseriram na economia de mercado, ocupando setores de atividade nos quais a intensidade capitalista permanecia fraca. Elas permitiram a diferentes atores de mobilizar, eles mesmos, fundos para atividades que lhes eram necessárias e que eram deixadas de lado pelos investidores. Na Europa, vários tipos de cooperativas se consolidaram: cooperativa de consumo na Inglaterra; cooperativa de habitação na Alemanha, Grã-Bretanha e Suécia; e, um pouco em todo lugar, cooperativas agrícolas. Em países onde a industrialização foi menos rápida, como na França ou na Itália, as cooperativas operárias de produção se impuseram, favorecidas na Itália pelo organização de distritos industriais da terceira Itália. Ainda que elas tenham se beneficiado de certos arranjos negociados com o Estado, elas foram principalmente submetidas à concorrência. Deste fato, a lógica geral de concentração de meios de produção levou-as a se especializarem em uma atividade principal ligada à identidade de seus membros, provocando um isomorfismo mercadológico (Enjolras, 1996). A preocupação com a perenidade das empresas atenuou mais amplamente o projeto político e essa transformação continuou, a tal ponto que "são verdadeiros grupos financeiros que surgem progressivamente como instituição; cooperativas típicas de economias capitalistas desenvolvidas" (Vienney, 1982, p. 108).

O advento do Estado-Providência modifica, quanto a ele, o papel desempenhado pelas mutuelles. Várias iniciativas associativas de socorro mútuo tinham se organizado para tratar dos problemas de incapacidade no trabalho, de doença e de velhice, reagrupando os membros de uma profissão, de uma categoria ou de uma localidade. Meios de emancipação operária para os socialistas, barreiras contra agitação social para os liberais e conservadores, essas mutuelles foram toleradas e controladas pelas autoridades, como na Bélgica e na França. Em seguida, os níveis de modalidade de contribuição e de prestação foram homogeneizados ao nível nacional, o que engendrou um endossamento ao Estado por todas as prestações que elas fornecem. De fato, o risco inerente a essas 
prestações pode ser melhor controlado graças à participação de um grande número de aderentes a nível nacional, complementado com técnicas estatísticas: a secularização do sistema foi portanto obtida com a instauração de seguros obrigatórios (doença, velhice...) e as mutuelles tornaram-se seguros complementares de regimes obrigatórios, ou até mesmo gestores da previdência social na Bélgica ou na Alemanha. Podese falar de isomorfismo não mercantil no sentido de que elas se submeteram às normas editadas pelo Estado e se inscreveram na economia não mercantil para complementar as transferências sociais, mesmo tendo que aperfeiçoar o princípio de adesão voluntária para entrar no campo da previdência coletiva complementar. Esse processo de institucionalização teve três configurações: uma lógica bismarckiana ou corporativista do seguro social apoiada no trabalho assalariado na Alemanha, Bélgica e França; uma lógica beveridiana de solidariedade nacional que abandona toda referência a uma atividade profissional, numa perspectiva universalista de direito ao bem-estar para todos, ilustrada pelo caso dos países escandinavos; e, uma lógica residual de último recurso frente as deficiências da família e do mercado no Reino Unido (Tittmuss, 1974, Esping-Andersen, 1990).

O lugar das mutuelles não pode ser tratado sem que antes ele seja situado em relação ao Estado-Providência. Isso também é válido para o caso das associações que se multiplicaram no campo da saúde e dos cuidados para com os enfermos.

\section{Associações, Estado-Providência e serviços sociais}

Historicamente, os cuidados dispensados a crianças, pessoas idosas, ou doentes provém de um trabalho definido como "feito por afeição ou por um senso de responsabilidade para com o outro, sem esperar por isso algum tipo de retribuição financeira imediata" (Folbre, 1997, p. 139). A titulo de introdução, esse trabalho de proximidade era feito pelas mulheres (O'Connor, 1996) e os casos de problemas de dependência, devido à idade por exemplo, eram supostamente reveladores das suas responsabilidades para com a esfera privada, o que tinha como contrapartida restringir sua participação na esfera pública e seu acesso à cidadania (Pateman, 1998, p. 236-260). O período de expansão, chamado os Trinta Gloriosos, ${ }^{1}$ que se inicia depois da Segunda Guerra Mundial, modifica amplamente a situação nesse campo. A 
instauração do Estado- Providência conduz a um reconhecimento lento e progressivo desse trabalho de proximidade graças às primeiras formas de externalização que provêm da esfera pública, favorecidas pelas iniciativas associativas.

Nesse modo de interação entre iniciativas e poderes públicos, os serviços as pessoas conduzem diretamente ao financiamento através de recursos que emanam da redistribuição. Esses recursos são considerados como inscritos em políticas sociais alimentadas por impostos ou por recursos da previdência social. $\mathrm{O}$ Estado estabelece regras a respeito das profissões assalariadas que executam esse trabalho e a respeito das modalidades de prestação de serviços. Às relações de trabalho "fordista" que eliminam a participação do empregado e apagam a dimensão relacional dos serviços para defini-los como um conjunto de tarefas técnicas, somam-se relações de consumo "providencialistas" onde a acessibilidade aos serviços tem como contrapartida uma definição das necessidades monopolizada pelos "experts" e pelos aparelhos tecnocráticos, consagrando a empresa com modelos higienistas e biomédicos sobre o usuário (Bélanger, Lévesque, 1991). A ambivalência dos serviços sociais lhes é constitutiva: construída pela exclusão dos trabalhadores e dos usuários, esses serviços são, no entanto, objeto de uma "desmercantilização" já que podem ser acessíveis aos indivíduos e famílias independentemente de suas rendas. Além disso, essa desmercantilização não se difunde da mesma forma em todo lugar e as divergências nacionais se explicam pelos diferentes graus de "defamiliarização", ou seja de coletivização das responsabilidades relacionadas à família.

Toda vez, as diferentes modalidades estabelecidas em diversos países europeus não devem ocultar que a desmercantilização, se ela tem um poder inegável de acordo com os graus de defamiliarização, foi considerada como o meio mais apropriado durante os Trinta Gloriosos para se desenvolver os serviços sociais. Ela permitiu que se ultrapassasse a insuficiência de iniciativas inicialmente associativas, a saber: o particularismo, ligado à preferência por certos grupos; o paternalismo, ligado à idéia que a ajuda dada não se refere a um direito; o amadorismo e a ausência de continuidade ligada a volatilidade do benevolente (Salamon, 1990). Sob o impulso de ações coletivas que, no final da guerra visavam resolver problemas sociais considerados importantes por 
aqueles que os revelavam, se produz um deslocamento parcial do trabalho de proximidade em direção aos serviços sociais, aos quais os poderes públicos davam condições, sempre ditando as normas que os implicavam e controlando-os.

\section{A renovação associacionista}

Esse modo de construção dos serviços sociais foi, no entanto, abalado à medida que o consenso de que beneficiava o EstadoProvidência, se enfraquecia. Ligada às críticas a respeito dos modos de intervenção que fazem valer essa necessidade de uma democratização dos serviços pelos usuários envolvidos, uma efervescência associativa é registrada desde os anos de 1960. Ela se traduziu em números. Desta forma, o programa Johns Hopkins de comparação internacional do terceiro setor mostrou que, em 1990, as organizações sem fins lucrativos empregavam cerca de doze milhões de pessoas correspondendo ao tempo integral de oito países industrializados (Alemanha, Estados Unidos, França, Itália, Japão, Reino Unido, Suécia) ou em transição (Hungria), ou seja, um emprego a cada vinte. A porcentagem de emprego total equivalente a tempo integral é, em média, de 3,4\% e o emprego nessas organizações progrediu fortemente no decorrer dos anos 1980: na Alemanha e nos Estados Unidos as associações representaram 13\% dos empregos criados de 1980 a 1990. No mais, o trabalho benevolente que é efetuado representa 4,7 milhões de empregos equivalendo á tempo integral e a receita total dos 8 países considerados ultrapassa 3.000 milhares de francos, ou seja, em média 3,5\% do produto interno (Archambault, 1996; Salamon, Anheier, 1996, 1997). A pesquisa do CIRIEC (2000) que fornece os números mais recentes menciona que existem, no que lhe diz respeito, 1.473 .000 empregos em tempo integral no Reino-Unido, 1.281.927 empregos na Alemanha, 830 mil na França, 660 mil nos Países Baixos, 475 mil na Espanha e 415 mil na Itália. O setor de saúde e social é o melhor representado em países como a Alemanha e a Franca. Na Alemanha, seis grandes organizações "guardachuvas" agrupam 80 mil assalariados que empregam mais de um milhão de assalariados permanentes e um milhão e meio de temporários; na França, 20 mil associações surgem nesse setor e empregam aproximadamente 620 mil pessoas. Se o papel crescente das associações 
no emprego e na atividade é inegável, as modalidades do crescimento associativo são diversas.

Nos países escandinavos, novas organizações mostraram uma forma de agir diferente das associações mais tradicionais. Distanciandose de um ponto de vista político e cultural hegemônico dos anos 1970, elas propuseram, nos anos 1980, novas formas organizacionais e soluções aos problemas sociais locais (Klausen, Selle, 1996, p. 99-122). Dentre essas estão as organizações ditas "promotoras de projetos", na Dinamarca, constituídas a partir do forte envolvimento de uma ou várias pessoas e de cooperativas nos casos de guarda de crianças, na Suécia. Nesse país, em 1994, 1.768 estruturas não municipais de guarda funcionavam acolhendo $12 \%$ de crianças que se beneficiavam de estruturas de acolhimento e dentre essas 1.020 eram cooperativas de pais e 117 eram cooperativas de trabalhadores (Pestoff, 1997, 1998). A dinâmica associacionista se utiliza, inclusive prioritariamente, da forma cooperativa, o que reanima a perspectiva original da cooperativa como emanação de uma ação baseada na associação. A forma cooperativa contribui tanto para uma reconfiguração dos serviços já existentes quanto para a criação de novos serviços. A "cooperatizacão" dos serviços sociais (Lorendahl, 1997; Pestoff, 1998) corresponde, antes de tudo, à idéia de se aumentar o papel dos usuários, tais como o papel dos pais na organização do acolhimento de seus filhos, e ela foi admitida pelas autoridades sob as pressões financeiras que se exercem no setor público.

No outro extremo, nos países mediterrâneos, paradoxalmente, a mesma forma jurídica foi solicitada: o status cooperativo foi utilizado para propor os serviços que o setor público não conseguia assumir. $\mathrm{Na}$ Itália, as cooperativas sociais se impuseram em vários territórios graças à capacidade de assumir funções que não eram preenchidas anteriormente: recrutamento de pessoas excluídas do mercado de trabalho e estabelecimento de serviços para as pessoas. Elas se desenvolveram rapidamente já que, nascidas nos anos 1970, elas já são aproximadamente 3 mil em 1996. Agrupam cerca de 100 mil associados, e dentre eles 75 mil assalariados; elas mobilizam 9 mil benfeitores e prestam serviços a várias centenas de milhares de pessoas (Borzaga, 1998). Desse modo, na Itália onde o Estado tinha um papel dominante em setores como o da educação e da saúde, em outros lugares amplamente investidos pelo "terceiro setor" (Gui, 1993), sua recente dinâmica é notável. Ela prova que o sinal de confiança ligado ao constrangimento 
da não redistribuição (Hausmann, 1980; Ortmann e Schlesinger, 1997, p. 97-119) pode ser substituído por outras características próprias das cooperativas, como o dinamismo empresarial ou a participação das partes envolvidas, trabalhadores e usuários (Young, 1983; Borzaga e Mittone, 1997.

A lei de 1998 sobre as cooperativas de solidariedade social em Portugal agrupa os membros "efetivos" beneficiários dos serviços e os membros "voluntários", que trazem bens ou serviços não remunerados. As cooperativas com vocação social apareceram paralelamente na Espanha. A lei geral de 1999 trata das cooperativas de iniciativa social destinadas a fornecer serviços educativos, de saúde, de inserção ou qualquer outra necessidade social não coberta pelo mercado. A nível regional, existem na Catalunha cooperativas mistas de integração social; nos países Bascos e em Valença existem cooperativas de integração social. Por exemplo, nessa última região citada, certas cooperativas de trabalho associado formavam trabalhadores especialmente para ajuda em domicilio, evoluíram em direção a uma organização mista, agrupando produtores e consumidores (Sajardo-Moreno, 1996). A um nível menor, no Reino Unido as associações foram substituídas em certos campos por cooperativas sociais, para inserção ou para serviços como cuidar de crianças e prestar ajuda em domicilio.

O número de iniciativas, difíceis de recensear, não é superior a algumas dezenas, mas existem igualmente empresas comunitárias (community enterprise), numerosas na Escócia, e representando em todo território do Reino-Unido 400 unidades de produção em 1995, com 3.500 empregados. No mais, as associações contribuíram como paliativo para as faltas, como testemunha o exemplo dos playgroups criados para o acolhimento de jovens e crianças. Na Inglaterra e no País de Gales desde 1996, mais da metade das crianças que se beneficiavam de um acolhimento coletivo iam a um playgroup, serviço de acolhimento em tempo parcial para as crianças de menos de cinco anos, resultante de uma iniciativa parental reagindo contra a carência das fórmulas de guarda infantil.

O crescimento das cooperativas nas atividades que acabam de ser citadas está ligado à possibilidade legal de uma abertura das cooperativas, tradicionalmente baseadas em uma categoria homogênea, 
em direção a representação das diferentes partes envolvidas nos órgãos de decisão (voluntários, trabalhadores, consumidores, coletividades locais...), como a lei de 1991 permitiu na Itália. Por outro lado, não é de surpreender que as cooperativas de tipo social tenham se desenvolvido nos países onde o regime do Estado-Providência pouco solicitou as associações nas prestações de serviços e onde as associações são limitadas do ponto de vista de suas atividades econômicas. A situação é bem diferente nos países onde os poderes públicos tomaram como hábito a parceria estreita com associações.

$\mathrm{Na}$ Alemanha e na Áustria, as iniciativas foram qualificadas de "ajuda mútua" para traduzir o desejo de responsabilidade para com as pessoas que elas representavam. As iniciativas podem ser divididas em três subsetores: grupos semi-informais; grupos de "auto-assistência", unindo pessoas que passavam pelo mesmo problema; e grupos defendendo a causa de certas populações das quais eles não fazem parte. Eles se constituem sobre uma base voluntária e o trabalho profissional remunerado só intervém como complemento. Essas iniciativas somam 70 mil na Alemanha, com aproximadamente 2,65 milhões de pessoas engajadas (Evers, Bolde et al. 1999). Elas cresceram imensamente a partir da década de 1980 principalmente no campo da saúde e da ação social, entre 5 mil e 10 mil grupos apenas no campo da saúde. Elas criam raízes na crítica à burocratização dos serviços no setor público e nas grandes organizações de beneficiência que agrupam as associações mais antigas, com as quais elas coabitam já que em Viena, por exemplo, 65 mil crianças são acolhidas, uma metade pelo serviço público e a outra metade por associações ao mesmo tempo tradicionais e advindas de iniciativas ditas "de base" (Leichsenring, 1997).

Assim como na França, na Bélgica trata-se de renovar as formas associativas reconhecendo que a ausência de fins lucrativos não lhes garante o respeito dos usuários. Em nome disso, consideradas durante muito tempo principais prestadoras de serviços, as associações beneficiaram-se do quase-monopólio local no período dos Trinta Gloriosos. Como nesses diferentes países existia uma tradição de cooperação entre poder público e associações, as inovações adotaram esse status mas sobre bases renovadas e definindo como via central os 
funcionamentos associativos. Segundo seus promotores, é de sua capacidade suscitar uma expressão dos usuários no sentido de voice em Hirchsman (Pestoff, 1998), e mobilizar engajamentos voluntários diversificados como também encontrar novos equilíbrios financeiros apropriados em um contexto menos protegido que depende da legitimidade da proposta associativa de serviços. Um certo número de associações, quer sejam elas antigas e questionem seus comportamentos habituais, quer sejam elas recentes e proponham abordagens originais, tentam ajustar sua organização conseqüentemente. Desta forma, no campo da pequena infância, a inovação associativa foi a origem de modelos de acolhimento que implicavam os pais, como o lugar de acolhimento de participação parental promovida pela associação dos coletivos crianças-pais-profissionais na França. Iniciadas pelos pais, elas foram apropriadas por vários profissionais que encontravam nelas a oportunidade de criar seus empregos sempre atentos à qualidade das prestações verificadas pela via dos laços criados com os pais. Essas fórmulas de acolhimento coletivo foram as mais desenvolvidas nos anos 1980. Na França, em $1^{\circ}$ de janeiro de 1996 (Ministério da Saúde Pública e da Previdência, 1997), contamos 710 creches parentais tendo uma capacidade de acolher 11.294 crianças; dessas estruturas, 481 tinham capacidade para oferecer 7.937 lugares de "multi-acolhimento" reunindo creches coletivas e haltes-garderies. Mais globalmente, as iniciativas associativas permitiram, no decorrer dos últimos dez anos, criar dois terços dos lugares de acolhimento coletivo. Agrupamentos visando mobilizar as famílias não funcionaram tão facilmente para a prestação de ajuda em domicilio, isso à medida em que os problemas de se delegar tarefas se mostraram mais dolorosos de tratar para os domicílios envolvidos. Portanto, experiências suscitadas em sua maioria por profissionais críticos do modo de intervenção dominante, que eles julgavam muito despersonalizados, também se difundiram.

Em detrimento das diferenças nacionais, o renovar cooperativo e associativo valida a hipótese de pertencimento dessas duas estruturas jurídicas num mesmo conjunto e coloca em evidência duas dimensões decisivas.

- As experiências provaram que elas podiam iniciar mecanismos originais de criação da confiança em atividades nas quais o sucesso dependia, em parte, dessa confiança. Essa construção da confiança 
baseia-se geralmente no engajamento das diferentes partes envolvidas da demanda (Bem Ner, Van Hoomissen, 1991) facilitada por estruturas que limitam as possibilidades de enriquecimento individual. No cerne dessa dinâmica multistakeholder (Borzaga e Mittone, 1997; Pestoff, 1996) forma-se uma confiança interpessoal através da instauração de um espaço onde não predominam as funções estratégicas, instrumentais ou utilitárias, e na qual se exerce uma reflexão conjunta. É por isso que esses espaços podem ser qualificados "de espaços públicos de aproximação" (Eme e Laville, 1994; Laville, 2000) no sentido de que questões que antes eram camufladas na esfera do privado podem ser abordadas e debatidas até o resultado ser uma definição comum compartilhada por todos e que pode, então, servir como quadro de referência (frame no sentido de Goffman, 1974) para usuários e profissionais.

A confiança interpessoal é consolidada pelo estabelecimento de uma certa estrutura, que se concretiza, por exemplo, em um regimento. Obviamente toda produção de serviço pode ser definida como uma coprodução já que a participação do consumidor é requerida. Mas o que aconteceu nas cooperativas sociais na Itália, nas cooperativas de guarda na Suécia, as experiências associativas de community care no Reino Unido ou de serviços de aproximação na Alemanha, na França e na Bélgica ultrapassa de longe essa co-producão. Trata-se de uma construção conjunta da oferta e da demanda de serviços que não se contenta em solicitar os usuários como consumidores ou asujeitados no quadro de uma lógica funcional pública ou privada mas os integra como "cidadãos na esfera política e enquanto membros de uma comunidade e de uma família no meio informal" (Evers, 1997, p. 55).

Essa construção conjunta remete à presença das diferentes partes envolvidas: algumas vezes são profissionais críticos à respeito de suas intervenções habituais; podem ser também pessoas sensibilizadas por motivos pessoais ao tema tratado ou futuros usuários do serviço; podem ser igualmente indivíduos institucionalmente engajados em ações de mudança. Não se tem, portanto, uma representação igualitária dos diferentes atores do serviço mas, sim, a mobilização progressiva da pluralidade das partes envolvidas (profissionais, benfeitores, usuários...). Instituindo um espaço mediador, de compostos variados, ela permite que se ataque a incerteza informacional. Nesses serviços relacionais 
que pressupõem a entrada na intimidade dos usuários, não se trata, de fato, de uma simples assimetria informacional, mas de uma indeterminação causadora de ainda mais insegurança para as partes envolvidas: os usuários, assim como os prestadores, não podem delimitar as características exatas do serviço adotado antes que ele seja debatido. Quaisquer que sejam os problemas colocados em seguida pela institucionalização desses serviços, é possível reconhecer uma dinâmica nova através da criação de serviços relacionais, reatualizando a dimensão sociopolítica própria ao associativismo, na qual vem insistindo a pesquisa européia. O espaços de experiência e de palavras (Eme e Laville, 1999), constituídos sem nenhum interesse de rentabilização do capital ou de imposição de normas administrativas, ou até mesmo em reação a essas normas, foram a base da invenção de novos serviços. A elaboração dos serviços foi operada a partir dos mundos vividos dos usuários e dos profissionais graças à socialização de uma questão nunca resolvida antes. Este aspecto da emergência desses serviços, que se baseia na ação de um grupo, não deve ocultar a importância dos empreendedores que transformam o projeto em realidade, pois nesse caso são empreendedores cívicos, de postura mais coletiva que individual, mesmo se as personalidades implicadas mostram-se determinantes. A disponibilidade coletiva de empreender demonstrada pelos atores que se engajam não pode ser explicada pela espera de um retorno sobre o investimento.

- Para além de sua emergência fundada sobre a mobilização de fontes voluntárias, as experiências são levadas a encontrar um equilíbrio, procurando conduzi-lo por fontes mercantis e não mercantis. A autonomia que elas procuram incita-as a não entrar em uma relação de dependência com os poderes públicos, mas sua preocupação com a igualdade de acesso aos serviços e os benefícios coletivos que elas carregam, reclamam um financiamento público. São serviços mistos que elas querem promover em uma conjuntura onde os financiamentos dos serviços sociais pelo poder público se encontram fragilizados pela diminuição dos meios disponíveis do Estado-Providência.

Conduzidas por atores de origem socioprofissional diferente, essas iniciativas, quaisquer que sejam suas particularidades, deslocam as fronteiras instituídas entre o econômico e o social nunca provenientes completamente da economia de mercado ou da solidariedade estatal. 
As ações conduzidas contribuem para a criação de atividades econômicas e de emprego, sempre buscando reforçar a coesão social através de novas relações sociais de solidariedade. Elas tiram sua força do sentido com que investem os seus promotores. Pouco importa que elas se baseiem nas necessidades específicas de uma população, na vontade de inserir pessoas sem emprego ou no desejo de trabalhar para a preservação do meio ambiente, sua pertinência permanece ligada com a manutenção "de espaços públicos de aproximação", isso significa lugares que permitem às pessoas de tomarem a palavra, de decidirem, de elaborarem e de pôr em prática projetos econômicos adaptados aos contextos dos quais eles emergem. Sua especificidade não reside somente na sua dimensão de espaço público, ela reside também no seu modo de funcionamento econômico. As fontes mobilizadas combinam doação, fontes públicas e fontes ligadas à venda de serviços ou ao estabelecimento de convênios com os parceiros privados.

Desta forma, o objetivo que elas podem se atribuir é menos o da supressão de toda separação entre produtor e usuário do que uma democratização conjunta das relações entre usuários e das relações de trabalho (Lévesque, 1997). Dito de outra forma, a profissionalização não pode ser considerada como sinônimo de burocratização; ao contrário ela pode atestar status e direitos sociais para os assalariados com a condição de ficarem auto-limitadas, ou seja, comandadas pela escuta dos usuários. Essa conduta não podendo ser espontânea, a garantia da sua permanência depende tanto do respeito por suas formas de expressão individual e coletiva quanto da preocupação por um diálogo organizado entre as diferentes partes envolvidas nas atividades onde os interesses não coincidirão sempre.

\section{Os ensinamentos da história}

Duas constatações podem ser feitas por um exame das formas evolutivas de associacionismo. Primeiramente, o critério de não distribuição dos ganhos não é determinante para o olhar das configurações européias, é até mesmo possível defender a idéia de um movimento associacionista mais amplo do que aquele destacado nos status associativos. Em segundo lugar, a retrospectiva invalida as 
hipóteses de uma economia neoclássica sobre um lugar vazio entre o Estado e o mercado que seria ocupado pelas associações.

A primeira constatação tem implicações sobre a delimitação da amplitude do feito associativo. Por exemplo, a mais vasta tentativa de se compreender o tema conduzida em oito países, e depois ampliada para 22, foi o programa de comparação internacional, proveniente da universidade americana Johns Hopkins, que só se interessou pelas organizações sem fins lucrativos. A exclusão das cooperativas e das mutuelles, pelo motivo de que elas podem distribuir uma parte de seus benefícios a seus membros, não pode ser justificado no contexto europeu. Primeiro, algumas cooperativas, como as cooperativas de construção na Suécia, nunca distribuíram lucros. Em seguida, a distribuição dos supérfluos é em todo caso limitada, já que as cooperativas e mutuelles são advindas do mesmo seio que as associações, isso significa que elas não são formadas com uma perspectiva de rentabilização do capital investido mas com o objetivo de satisfazer um interesse coletivo ou um interesse mutuo (Gui, 1993), de contribuição ao bem comum ou de resposta a demandas sociais que certas categorias da população expressam (Laville e Sainsaulieu, 1997). Daí uma acepção mais ampla das organizações envolvidas na Europa: falamos de economia social mais do que de setor não-lucrativo. As lutas conduzidas no século XIX, levaram a compromissos legalizando a existência de organizações nas quais uma categoria de agentes, que não os investidores, se via atribuída da qualidade de beneficiários. Os status obtidos (cooperativo, mutualista, associativo) delimitam um conjunto de organizações de economia social nas quais não é a pressão da não lucratividade que é determinante, mas o fato que o interesse material daqueles portadores de capitais ser submetido a limites. A fronteira não passa, portanto, entre organizações com ou sem fins lucrativos, mas entre sociedade capitalista e organizações de economia social que privilegiam a formação de um patrimônio coletivo em relação ao retorno sobre o investimento individual e adotam status que restringem a apropriação privada dos resultados. O entrelaçamento entre associações e cooperativas na abundância das práticas observadas desde os anos 1970, confirma esta hipótese. 


\section{Quadro 1 - As duas definições do associacionismo}

\begin{tabular}{l|l}
\hline \multicolumn{1}{c|}{$\begin{array}{c}\text { Definição européia } \\
\text { de economia social }\end{array}$} & \multicolumn{1}{c}{$\begin{array}{c}\text { Definição americana } \\
\text { do setor não-lucrativo }\end{array}$} \\
\hline $\begin{array}{l}\text { Critério de limites trazidos para } \\
\text { apropriação privada dos resultados: } \\
\text { inclusão das cooperativas e } \\
\text { mutuelles. }\end{array}$ & $\begin{array}{l}\text { Critério de não redistribuição: } \\
\text { exclusão das cooperativas e } \\
\text { mutuelles. }\end{array}$ \\
\hline
\end{tabular}

Conseqüentemente, a definição adotada no estudo internacional da Universidade Johns Hopkins sofre um viés americano (Borzaga, 1998) porque ela se baseia sobre o critério da pressão de não redistribuição estruturando a configuração americana do setor, com forte papel das fundações. Esse critério não leva em conta as especificidades jurídicas dos países europeus onde o critério descriminante é a existência de limites à redistribuição. É este critério que confere às organizações da economia social diferenças em relação às outras organizações produtivas. Por mais díspares que elas sejam, as experiências européias tem em comum o fato de representarem uma tradição diferente da tradição americana. Elas identificam na associação uma expressão da cidadania e, portanto, uma contribuição ao "espírito público", incluindo não somente formas de voluntariado, mas também ações coletivas baseadas na ajuda mútua das mutuelles e a participação de cidadãos implicados com problemas sociais, com uma dimensão reivindicatória de intervenção econômica e social. Por isso, a dinâmica associacionista só pode ser percebida se as formas jurídicas associativas forem re-situadas em um conjunto mais vasto, incluindo cooperativas e mutuelles.

A segunda constatação conduz a ligar ação associativa e ação pública, já que as duas são advindas da resistência à utopia de uma sociedade de mercado, promovida pela corrente liberal desde o século XIX, e estão profundamente entrelaçadas. Enquanto que as diferentes declinações das teorias da escolha institucional faziam das associações organizações, intervindo em caso de debilidade do mercado ou do Estado, a realidade história enfraquece essa perspectiva. Na realidade, o désencastrement (Polanyi, 1983) do mercado, conduziu a reações por parte da sociedade, dentre elas a constituição de associações e a construção de um Estado social protetor. É esse processo histórico que 
Salamon (1997, 1990) lembrou, ressaltando que as associações eram efetivamente "a primeira linha de defesa" (Lewis, 1997, p. 166) elaborada pela sociedade, mas suas fraquezas (insuficiência, particularismo, paternalismo, amadorismo), em seguida, obrigando-as uma cooperação com o Estado. Mas esta explicação funcionalista não esgota o tema como o reconheceram Salamon e Anheier $(1996,1997)$ eles próprios quando, na seqüência da primeira pesquisa Johns Hopkins, se orientaram em direção "a uma aproximação em termos de origens sociais" destinada a melhor compreender as situações nacionais através de uma análise de sua gênese histórica. Daí, a noção de "setor da sociedade civil" (Salamon e Anheier) que introduziu uma abertura interessante para se perceber a inscrição das associações na sociedade, mas tem como proposta assimilar de maneira muito rápida o setor associativo ao conjunto da sociedade civil e não analisar suficientemente as interações com o Estado e o mercado.

Além disso, a perspectiva histórica busca caracterizar as associações menos como organizações privadas, o que elas são a partir do momento onde seu status garante autonomia de decisão e de gestão, do que como instituições intermediárias permitindo o acesso à esfera pública indissociável da comunidade política. O que faz a originalidade da associação moderna é sua relação com o espaço público, esse espaço de confrontação possível entre cidadãos de uma mesma democracia regidos por princípios de liberdade e igualdade, condição de um mundo comum ao mesmo tempo que prova sua existência. O compartilhamento próprio à associação remete à comunidade política, ou seja, "uma comunidade que nenhuma origem comum funda ou justifica enquanto ela recusa por princípio toda a comunhão final" (Tassin, 1992, p. 54). Em termos durkheiminianos, sua modernidade está ligada ao fato de que ela participa "de uma sociedade que nada transcende mas que transcende todos seus membros" (Lazar, 2000, p. 406).

Enfim, essa inscrição no espaço público realiza-se a partir de vínculos interpessoais. A associação delimita um espaço operando a passagem da esfera privada à esfera pública através de um encontro interpessoal. Podendo revelar ao mesmo tempo o princípio societário e o princípio comunitário, o fato associativo se expande em duas interfaces; na primeira, a personalidade importa mais do que as funções e, na 
segunda, as funções importam mais do que a personalidade, ele possibilita aquilo que poderíamos chamar de "espaços públicos primários baseados num interconhecimento" (Caillé, 1998, p. 79).

As variações desta "interconexão" podem ser muito variáveis. Em referência aos dois modos de solidariedade que foram mencionados, de fato existem duas matrizes da ação associativa que tentam assumi-la de maneira própria. A lógica de intervenção para outrem ou de ajuda social corresponde à atitude na qual os promotores produzem uma ação que eles estimam necessária ou desejável para um grupo de beneficiários, do qual eles não fazem parte. A lógica da auto-organização ou da ajuda mútua (entraide mutuelle) corresponde a uma atitude na qual os promotores colocam em prática uma ação para o grupo do qual eles estimam fazer parte. Mas existem também tendências que priorizam o espaço associativo concebendo-o como a reprodução de um espaço privado já constituído, são portanto lógicas domésticas que se põem em prática. Existem, no outro extremo; as opções que consistem em "secundarizar" o espaço associativo, considerando-o como um movimento social onde as relações personalizadas valem menos que a capacidade coletiva de pensar sobre o sistema institucional para forçálo a mudar; a lógica de ação é, por conseguinte, o registro cívico.

A dimensão política da associação não consegue, no entanto, fazer esquecer a sua dimensão econômica de produção de bens e serviços e a sua dimensão de contribuição ao elo social.

A associação não dissocia os campos da economia, do social e do político; o que, inclusive, causa dificuldades de análise, já que muitos estudos se concentram em um desses campos segmentando-os pela construção ou procedendo enfoque monodisciplinares. Ao mesmo tempo que a associação funciona como intermediária entre espaços privados e espaços públicos, ela é intermediária entre o espaço político e o econômico: essas duas dimensões coexistem no fato associativo, mesmo se as associações concretas podem ponderá-las de maneira contrastada e privilegiar uma ou outra. As lógicas de ação domestica priorizam a socialização e a reprodução de relações hierarquizadas entre seus membros através de uma atividade econômica que deve contribuir para 
a sua estabilidade, ao passo que as lógicas de ação cívica dão prioridade à ação política, as atividades econômicas e as relações sociais desempenham um papel de suporte para esta última. No que se refere às lógicas de ação social e de ajuda mútua, elas atribuem uma importância primordial aos bens e serviços fornecidos. Segundo a terminologia econômica, a lógica de ação social pode ser qualificada de lógica de interesse geral, porque a categoria dominante, definida como a categoria que detém o poder de decisão em última instância, exerce uma atividade em proveito de uma categoria beneficiária distinta; a lógica de ajuda mútua se propõe a atingir um interesse mútuo, já que as categorias dominante e beneficiário fundem-se (Gui, 1993).

Essa imbricação de interesses econômicos, sociais e políticos sugere que a iniciativa não ressalta somente uma racionalidade formal ou instrumental, ela inclui a referência a valores ou crenças como um desejo de intercompreensão. As pessoas envolvidas são mais atores de mudança ou empreendedores, no sentido de Weber e Schumpeter, do que indivíduos apenas racionais. Eles possuem uma capacidade de pensar a novidade, de ir além das críticas que ela levanta, misturando assim elementos racionais e emocionais (Lévesque, 1997). Sobre este tema, Young (1981) desenvolve uma série de perfis de empreendedores "sociais" para quem a procura do ganho monetário cederia lugar à procura de autonomia ou de espaço de criatividade... Fundamentalmente, os indivíduos não se comportam somente como atores econômicos, são também membros de famílias ou comunidades (local, étnica, profissional...). São também cidadãos na esfera política. E é precisamente este cruzamento aberto e ao mesmo tempo indefinido destas dimensões de identidade, no seio do espaço público de nossas sociedades, que constitui o espaço associativo como esfera intermediária.

Para além dos proveitos individuais, a iniciativa associativa revê uma dimensão coletiva que implica na duração da elaboração do projeto, a ação sendo tributária da qualidade e da intensidade da reflexão que a precede e a acompanha (Levesque, 1997). Porque o vínculo precede o bem, a associação é marcada pela força da doação, entendida como uma "prestação de bens e serviços efetuada sem garantia de retorno em vista de criar, entreter ou regenerar o vínculo social" (Caillé, 1998, p. 75). No entanto, ela não saberia ser considerada como o domínio de um altruísmo "puro" ou da gratuidade. Misto complexo de desinteresse e 
interesse, as motivações e as razões de agir que na associação se encontram testemunham que ela é particularmente permeável às condições societárias nas quais ela se modela, em particular aos contornos do sistema institucional. Daí, uma conceitualização que insiste na dimensão intermediária do fenômeno associativo, ressaltando seu "caráter fundamentalmente aberto, pluralista e intermediário".

Esta concepção se traduz particularmente pelo recurso a uma representação triangular para analisar o fato associativo integrando "a grande variedade de fatores" que o constituem e o influenciam (Evers, 1997, p. 52). Esse quadro analítico serve de referência a diversos autores [Eme, 1991; Evers, 1990; Laville, 1992, 2000; Kramer et al., 1993; Pestoff, 1992, 1996, 1998] e foi tomado como referência em trabalhos do serviço de desenvolvimento territorial do programa Local Economic and Employement Development (LEED), da Organização para a Cooperação Econômica e do Desenvolvimento (OCDE, 1996).

\section{A perspectiva da economia plural}

A perspectiva da economia plural insiste sobre a pluralidade dos princípios econômicos que pode induzir a contribuições convergentes de autores tais como Boulding (1973), Mauss (1923), Perroux (1960), Polanyi (1983) ou Razeto Migliaro (1988) que propõem uma extensa definição da economia distinguindo três princípios.

- O princípio do mercado permite um encontro entre a oferta e a demanda de bens e serviços para fins de troca através da fixação de preço. A relação entre aquele que oferece e aquele que demanda se estabelece sobre uma base contratual a partir de um cálculo de interesse. O princípio do mercado não supõe uma imersão nas relações sociais "consideradas hoje pelas culturas ocidentais como sendo distintas das instituições pensadas como econômicas" (Maucourant, Servet, Tiran, 1998). Ele não é necessariamente produzido pelo sistema social, ao contrário dos outros princípios econômicos a seguir.

- A redistribuição é o princípio segundo o qual a produção é confiada a uma autoridade central que tem a responsabilidade de repartila, o que supõe um procedimento definindo os regulamentos dos impostos e seu destino. De fato se estabelece assim uma relação de tempo entre a 
autoridade central, que impõe uma obrigação, e os agentes que se submetem.

- A reciprocidade corresponde a uma relação estabelecida entre grupos ou pessoas graças a prestações que só fazem sentido no intuito de manifestar um elo social entre as partes envolvidas. $\mathrm{O}$ ciclo da reciprocidade se opõe à troca mercantil, porque ele é indissociável das relações humanas que colocam em jogo desejos de reconhecimento e de poder e ele se distingui da troca redistributiva, na medida em que ele não é submetido a um poder central. Uma forma específica de reciprocidade é esta que se exerce no seio da célula de base que é a família, denominada por Polanyi de administração doméstica.

A partir desses três princípios de base, a economia própria a modernidade democrática pode ser decomposta e analisada através três pólos:

- A economia mercantil corresponde à economia na qual a distribuição de bens e serviços é confiada prioritariamente ao mercado. Não se trata de maneira alguma de pretender nem que a economia mercantil é a emanação do mercado único, nem que ela se limita a um sistema de preços concorrenciais. A economia mercantil não é unicamente organizada ao redor do mercado e ela admite numerosas contribuições não-mercantis, nem que sejam só as ajudas e as subvenções oferecidas às empresas. Isso dito, a combinação realizada em seu seio se singulariza pela prioridade acordada ao mercado e pela subordinação dos suportes não-mercantis e não-monetários a este. Se parece difícil reter o corte entre economia de mercado e capitalismo que Braudel introduziu (Caillé, 1982, 1983), em contrapartida a tensão entre desregulamentação e regulação pode ser considerada como constitutiva da economia mercantil. Historicamente, um conjunto de mercados regulados foi substituído no século XIX por um mercado auto-regulador que fez ele mesmo engendrar a criação de instituições reguladoras (Verley, 1999, p. 66-69). "A maioria dos mercados que existem hoje são antes de tudo regras, instituições, laços que enquadram e controlam a formação e o encontro da oferta e da demanda". Mas eles são contestados por um novo sopro de desregulamentação apelando para “o alinhamento desses diversos mercados sobre uma norma ideal e impessoal do mercado concorrencial perfeito, uma dessocialização dos mercados" (Gadrey, 1999). A definição da economia mercantil é portanto uma 
questão "política, altamente conflituosa" (idem) que não cessa de se colocar.

- A economia não mercantil corresponde à economia na qual a distribuição dos bens e serviços é confiada prioritariamente à redistribuição. Ela pode ser privada quando emana de uma instituição privada, ou seja, de uma pessoa moral em que os dirigentes têm o poder de tomar uma porcentagem dos lucros obtidos com fins de proteção ou de doações, por exemplo, pelo intermédio de doações privadas. Mas a redistribuição é, sobretudo, pública: é ao redor do Estado social que se agenciou uma forma moderna de redistribuição, alimentada por impostos obrigatórios, e pela qual são dadas alocações atestando direitos sociais. A redistribuição se exerce amplamente pelo viés do serviço público de onde as regras são decretadas por uma autoridade pública submetida ao controle democrático (Strobel, 1995).

- A economia não monetária corresponde à economia na qual a distribuição de bens e serviços é confiada prioritariamente à reciprocidade e à administração doméstica. De certo, um número considerável de relações recíprocas se utilizam de formas monetárias, mas é bem no seio da economia não monetária que se encontram em prática as principais contribuições recíprocas através da autoprodução e da economia doméstica.

Cada pólo da economia é portanto organizado ao redor da predominância de um princípio (Eme, 1998, p. 219), mas, a partir desses pólos, se estruturam combinações historicamente variadas. É, em todo caso, o que sobressai da evocação da gênesis e da evolução dos diferentes componentes da economia contemporânea.

\section{Quadro 2 - O triângulo da economia plural}

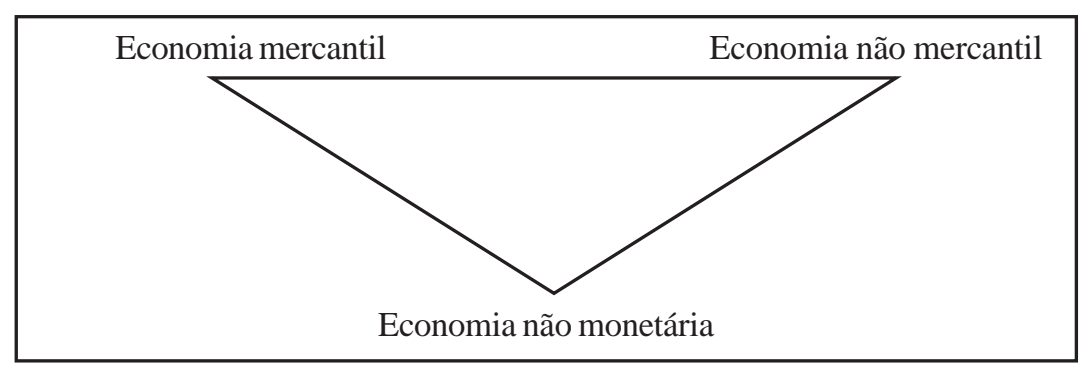

Fonte: Roustang, Laville, Eme, Mothé, Perret (1997) 
As associações podem, então, ser abordadas como um componente da economia que redescobre o potencial organizador da referência à solidariedade. De certo, o sucesso do Estado social conduziu ao esquecimento da matriz da entre-ajuda mutuelle que a tinha em parte produzido, mas os limites de uma ação unicamente estatal tornaram-se patentes, como atestam os debates sobre a inserção. Nessas condições, as duas fontes de solidariedade democrática podem ser consideradas. É, em todo caso, na união desses dois pensamentos de solidariedade para conceber dispositivos de proteção apropriados à presente situação que nos convida à perspectiva solidária. É o que indicam, de fato, as iniciativas desenvolvidas no último quarto do século $\mathrm{XX}$, que reataram com o élan associativo da primeira metade do século XIX, colocando no centro da sua passagem para a ação econômica uma referência à solidariedade, entendida como reciprocidade democrática. Contrariamente aos postulados de Gorz, o impulso recíproco inicial não se prolonga pela instituição de um setor autônomo, mas por uma articulação com os princípios de redistribuição e de mercado, única capaz de evitar o esgotamento dos atores na gestão da penúria. Se a manutenção de um equilíbrio entre os diferentes princípios econômicos (reciprocidade, redistribuição, mercado) a serviço de finalidades associativas impõe desafios arriscados, ele não é menos desejado pela maioria dos promotores que rejeitam um trancamento em um setor "à parte" e reivindicam o acesso ao direito comum.

As atividades econômicas criadas se consolidam caso elas consigam articular os diferentes registros da economia de maneira apropriada aos projetos para conseguir uma combinação equilibrada entre diferentes recursos (recursos mercantis obtidos pelo produto de vendas, recursos não mercantis provenientes da redistribuição, recursos não monetários advindos de contribuições voluntárias). Esta constatação incita no avanço da idéia geral de hibridação como modo de perenizar. A hibridação entre recursos advindos de economias mercantis, não mercantis e não monetárias choca-se fortemente com o fechamento de economias sobre a qual é baseada a arquitetura institucional que separa o mercantil do não mercantil e esquece da existência de atividades não monetárias. 


\section{Quadro 3-A economia solidária}

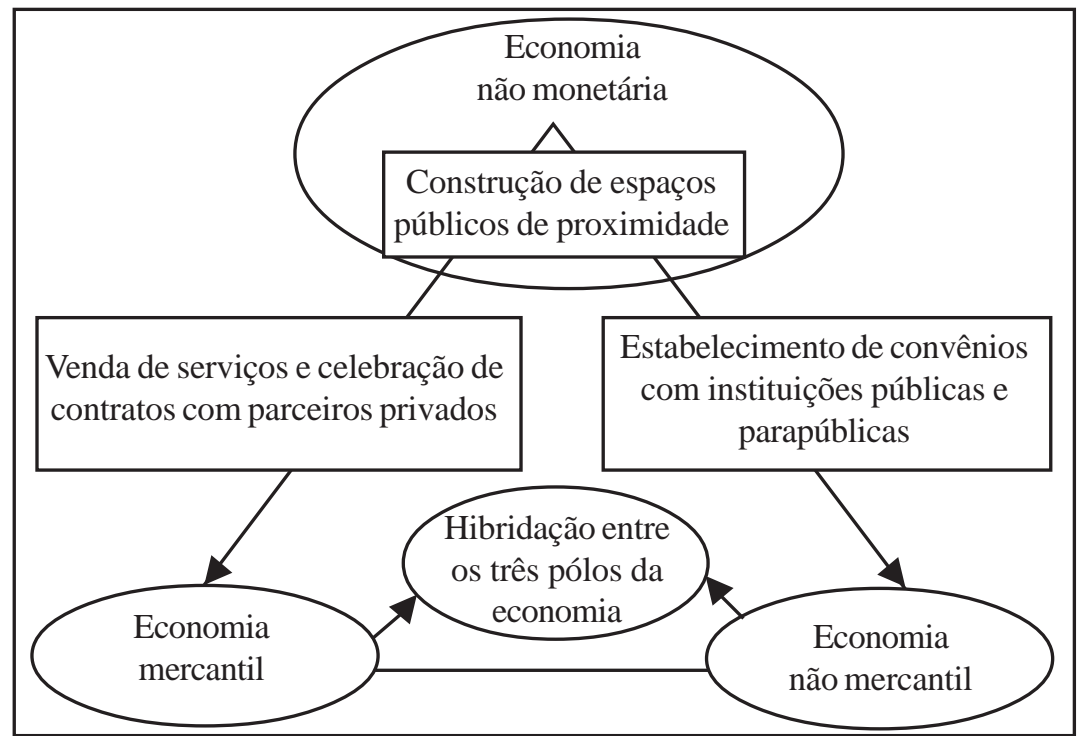

Fonte: Eme, 1991; Laville, 1992, 1994.

De maneira mais extensiva, a economia solidária pode ser definida como o conjunto das atividades contribuindo para a democratização da economia a partir do engajamento dos cidadãos. Contrariamente ao que poderia fazer acreditar a apropriação da palavra solidariedade pelos promotores de algumas ações caritativas, a economia solidária não é um sintoma do desregulamentação que gostaria de substituir a ação pública pela caridade, nos remetendo a mais de um século atrás. Ela emana de ações coletivas visando instaurar regulamentos internacionais e locais, completando os regulamentos nacionais ou complementandoos quando for necessário. Não se trata de substituir a solidariedade redistributiva por uma solidariedade mais recíproca mas, de definir modalidades de acoplamento para completar a solidariedade redistributiva por uma solidariedade reciproca que pode ser um fator de produção e portanto participar na criação de riquezas. É em direção a essa constatação que convergem várias pesquisas: elas mostram que na ação econômica são mobilizados recursos complementares ao capital financeiro e humano que podem ser reagrupados sob o conceito de capital social. Com esse titulo, o capital social formado a partir das relações 
de solidariedade não pode ser negligenciado na economia. É um fator de produção que pode contribuir para melhorar os resultados da combinação produtiva, segundo as palavras de Razeto Migliaro (1998) que o denominou de "fator C" como cooperação. A economia solidária, concebida como uma forma de democratização da economia e não como um ressurgimento da filantropia pode, portanto, articular as dimensões recíprocas e redistributivas da solidariedade para reforçar a capacidade de resistência da sociedade à automatização social, ela própria ressaltada pela monetarização e mercantilização da vida cotidiana (Perret, 1999). A multiplicidade de práticas socioeconômicas que surgiram nos últimos vinte anos para responder a questões colocadas pelas mutações contemporâneas ratifica, portanto, a perspectiva de uma economia solidária e de uma proteção social mista: propondo aumentar conjuntamente as oportunidades de socialização democrática e a oferta de trabalho, questionando politicamente as relações da economia e do social, elas tentam atacar, ao mesmo tempo, a crise da integração social pelo trabalho e a crise dos vínculos civis e cívicos (Lipietz, 2000).

\section{Os fatores da renovação}

A problemática da proteção social e da economia pluralista permite ler de outra maneira as práticas associativas. Existe uma tensão inerente às associações entre as dimensões social, econômica e política. Certamente elas podem ser separadas em uma "subeconomia" ou em uma "gestão da urgências". Mas sua originalidade sócio-econômica pode também lhe conferir uma postura política, com a condição de que suas atividades se mantenham subordinadas à realização de fins políticos e que elas não se prestem, como numerosas organizações de economia social, aos fenômenos de isomorfia institucional. Assumir um papel social e econômico sempre se perguntando a respeito dos objetivos políticos que são de sua responsabilidade promover, indica uma via susceptível de contornar duas armadilhas sintomáticas aos itinerários associativos: a focalização sobre o projeto, ignorando que a organização produz quotidianamente efeitos estruturais sobre as relações entre os membros e persistindo em um projeto cada vez mais afastado da realidade vivida; 
a obsessão gestionária que governa progressivamente toda a identidade própria à associação e podendo até resultar na supressão do projeto que lhe dava sentido. Ser responsável por novos campos de atividade pode então ser compreensível, não como um distanciamento em relação ao que está em jogo na arena política, mas como o resultado complexo de fatores que são, ao mesmo tempo, sociais, econômicos e políticos.

\section{Fatores socioeconômicos}

O ressurgimento associacionista que é registrado durante o período das mutações está primeiramente relacionado com as evoluções sociodemográficas que colocam novamente em questão a uniformização que se havia imposto durante o período de expansão: envelhecimento da população, diversificação do perfil dos domicílios, aumento da atividade feminina.

Enquanto que, nos anos 1960, a inserção das mulheres no mercado e a conciliação entre vida profissional e vida familiar não figuravam entre as prioridades públicas, a não ser nos países escandinavos, a progressão em todos os países europeus da atividade profissional mudou essa estrutura. Se a Suécia permanece em primeiro lugar nos países europeus com uma taxa de atividade feminina de mais de $75 \%$ para as mulheres entre 16 e 64 anos, essa taxa atingiu uma média na Europa de $44 \%$, em 1992, contra 22\%, em 1960, e 30\%, em 1980. Apesar das dificuldades de comparação, particularmente devido a ponderações muito variáveis do tempo parcial, essas taxas atestam modificações que têm resultados diretos nos modos de vida familiar. Em contrapartida, a proporção européia daqueles domicílios com uma só pessoa aumenta, ela era de $24 \%$, em 1991, contra $16 \%$, em 1971. Essa evolução se acompanha de um aumento das famílias mono-parentais, sua parte no total das famílias que têm crianças de menos de 15 anos, passou, entre 1981 e 1991 , de $9,4 \%$ para $15,4 \%$ na Alemanha, de 8,3\% para $10,3 \%$ na França, e de $13,7 \%$ para $19 \%$ no Reino Unido (Hantrais e Letablier, 1995; Sauviat, 1996). No que se refere à população idosa, na Europa contava-se em 1993, 19,7\% de pessoas idosas de mais de 60 anos, das quais doze milhões tinham mais de 80 anos (Laville, e Gardin, 1997). Essas tendências subentendem, ao mesmo tempo, uma diversificação e 
uma intensificação das demandas de serviços. As demandas que se afirmam são aquelas para serviços exercidos no domicílio da pessoa (limpeza, passar a roupa, cozinhar, manter a casa limpa, trabalho de jardineiro...) que não tinham sido objeto de externalização antes: é assim que se torna possível distinguir, no seio dos serviços da vida cotidiana, de um lado, os serviços que agrupam outros respondendo às necessidades relacionadas à situação familiar (cuidar de crianças) ou a uma situação de dependência (pessoas idosas, doentes ou privadas de autonomia) nas quais a relação entre prestador e usuário está no centro dos serviços; por outro lado, os serviços domésticos que se referem mais a questões materiais englobam o conjunto dos serviços prestados em domicílio, que facilitam a vida cotidiana, por exemplo, diminuindo o peso do entretenimento do domicílio.

O aumento das novas demandas é atestado por uma evolução geral do emprego nos países desenvolvidos. Dois grandes tipos de atividades com trajetórias contrastadas podem ser distinguidas:

1) As indústrias e os serviços em larga escala comportando os serviços logísticos (transporte, grande distribuição, tratamento de esgoto...) e os serviços administrativos (banco, seguros, administração...) que se aproximam das atividades de produção em massa ou em série. Esses serviços intervindo a título principal sobre os objetos, sistemas técnicos ou tratando de informações codificadas foram modificados pelo recurso das novas tecnologias da informação. Eles têm, portanto, trajetórias convergentes com as atividades industriais marcadas por dois traços: uma restrição de sua capacidade de criação de emprego em relação aos Trinta Gloriosos e um aumento da qualificação ao empregar.

2) Os serviços relacionais, ao contrário, como o ressaltaram Baumol (1987) e Roustang (1987), atribuem um lugar central à relação de serviços porque a atividade é baseada na interação direta entre prestador e destinatário. Eles visam a influenciar o funcionamento da organização para os serviços com as empresas e a melhorar o estado físico, intelectual ou moral dos clientes-usuários quando se trata de serviços com as pessoas. As novas tecnologias são apenas suportes a relação, 
oferecendo opções adicionais quanto à variedade e à evolução qualitativa da prestação. A inovação no processo de produção não termina necessariamente em uma padronização. Ela pode se concluir como uma inovação, o trabalho complexo não foi eliminado, mas deslocado. Um efeito variedade e qualidade chega para compensar o efeito de substituição do capitaltrabalho, o que permite a esses serviços relacionais serem criadores de novos empregos. Inclusive, apesar das dificuldades devidas aos modos de organização das compatibilidades nacionais que não isolam esses serviços relacionais, os números disponíveis mostram que eles estão no cerne da criação de empregos. No total, nos países da Organização para a Cooperação e o Desenvolvimento Econômico (OCDE), o comércio, o serviço as empresas, hotelaria-restauração, os serviços personalizados e domésticos, a educação, a saúde, a ação social e a administração pública representam uma maioria e uma parte sempre crescente dos empregos. Certos subgrupos, tais como a educação, a saúde e a ação social, os serviços coletivos sociais e personalizados, os serviços domésticos, revelam um impulso específico sustentado por tendências sociodemográficas pesadas (Borzaga, 1998).

\section{Quadro 4 - Taxa de crescimento do emprego entre 1993 e 1997 no conjunto de setor dos serviços e dos subconjuntos "educação, saúde e ação social, serviços coletivos, sociais e personalizados, serviços domésticos"}

\begin{tabular}{l|c|c}
\hline \multicolumn{1}{c|}{ Países } & Conjunto dos serviços & Subconjuntos \\
\hline Itália & $2,3 \%$ & $4,1 \%$ \\
\hline Bélgica & $5,4 \%$ & $6,2 \%$ \\
\hline Alemanha & $4,2 \%$ & $6,1 \%$ \\
\hline Espanha & $12,2 \%$ & $16,3 \%$ \\
\hline França & $3,9 \%$ & $10,5 \%$ \\
\hline Reino Unido & $8,8 \%$ & $11,1 \%$ \\
\hline
\end{tabular}

Fonte: Eurosat, pesquisa sobre as forças de trabalho. 
No entanto, o impulso dos serviços relacionais se deparou com o sufocamento das formas de regulação pública que tinham caracterizado os Trinta Gloriosos e haviam permitido o desenvolvimento dos serviços sociais. A desmercantilização destes tirava sua força do crescimento dos meios do Estado-Providência, condicionado pelo ritmo da taxa de crescimento. Com a desaceleração das taxas de crescimento inicia-se a crise do Estado-Providência. Sua estabilidade financeira é questionada pela estagnação das receitas públicas e das políticas de restrição dos déficits orçamentários cada vez mais difíceis de conduzir à medida que o desemprego e a exclusão crescem.

\section{Fatores políticos}

Tentativas de renovação da intervenção dos Estados-Providência foram imaginados para ultrapassar esta crise. Elas representaram um primeiro fator político de apelo às associações para remediar as "disfunções" institucionais. A multiplicação de barreiras no mundo administrativo, como a distância separando as instâncias públicas das empresas privadas, estimularam uma tendência para se utilizar a forma associativa a fim de impulsionar novas formas de governo reunindo eleitos, organizações privadas e públicas, parceiros sociais. Essas coordenações inter-institucionais destinam-se a promover abordagens mais integradas para os problemas que se colocam sobre um território partindo de um diagnóstico ao menos parcialmente compartilhado, elaborado a partir das percepções dos diferentes participantes. Esses parceiros, se podem mudar incontestavelmente os comportamentos institucionais, também podem confinar os acertos aos experts que organizam entre eles uma engenhosidade social sem que isso resulte num progresso da participação cidadã.

É por isso que, apesar da novidade dessa estimulação associativa pelas instituições, o principal motivo da dinâmica associacionista está em outro lugar. Como indicam os dados empíricos, ela reside na elaboração daquilo que pode ser denominado uma politização da vida cotidiana.

Durante muito tempo, certas facetas da sociedade não podiam ser questionadas ou porque revelavam o espaço privado ou porque se 
baseavam em representações sociais incontestáveis. Desde os anos 1960, as alterações nos modos de vida introduziram "no campo discursivo aspectos da conduta social que eram antes intangíveis ou regulados por práticas tradicionais" (Giddens, 1994, p. 120). Essa capacidade autoreflexiva ilustra-se através de movimentos como o feminismo ou a ecologia. Novos movimentos sociais surgem alimentando assim as reivindicações no trabalho e no consumo. A falta de possibilidade de implicação para os assalariados assim como para os usuários, tanto no trabalho quanto no consumo, é criticada da mesma maneira que a perspectiva padronizadora da demanda orientando a oferta em direção aos bens de massa e aos serviços estereotipados. Nasce então a exigência de uma maior "qualidade" de vida; cada vez mais se opõe ao crescimento quantitativo à reivindicação de um crescimento qualitativo. Trata-se de "substituir uma política do modo de vida por uma política do nível de vida" (Roustang, 1998), de considerar as dimensões de participação das diferentes esferas da vida social, de preservar o ambiente, de mudar as relações entre os sexos e as idades. Surgem vozes para duvidar da capacidade de intervenção pública em remediar as insuficiências do mercado. Usuários denunciam as lógicas burocráticas e centralizadoras das instituições redistributivas, segundo eles, a falta de aptidão para a inovação gera a inércia, o controle social e o clientelismo; mais grave ainda, a inadequação perante situações de vidas diferenciadas explica a sobrevivência de fortes desigualdades por detrás de uma aparente normalização igualitária.

Essas formas de expressão inéditas assinalam uma modificação tendencial nas formas de engajamento no espaço público. O militantismo generalista, associado a um projeto de sociedade implicando uma ação na duração e fortes delegações de poder no quadro de estruturas federativas se enfraquece como mostra o recuo de alguns pertencimentos sindicais e ideológicos. No entanto, nessa crise do benevolente, constatada dentre as associações mais institucionalizadas, se acumula uma efervescência associativa com base em engajamentos concretos por tempo determinado, centrados em problemas específicos e se dispondo a colocar em prática respostas rápidas para os temas em questão (Ion, 1997; Barthélémy, 1994, p. 48). As associações se especializam e as atividades esportivas, culturais ou de lazer ganham mais espaço na criação de associações que aumentam (Juan, 1999). A questão que se coloca é aquela do voluntariado ou da participação política e social. 
Distanciadas dos movimentos sociais, as ações coletivas mesclam cooperação social, ajuda mútua e protestos.

Mais amplamente a associação participa da reatualização do tema da sociedade civil, não numa versão inocente que a colocaria em oposição ao Estado, mas questionando-se sobre "a questão da articulação, da mediação, da junção do político não-institucional ao político institucional, dos espaços públicos de proximidade aos espaços públicos de delegação, da sociedade civil ao Estado" (Maheu, 1991). É certo que a noção de sociedade civil apresenta dificuldades porque foi utilizada com sentidos diferentes, às vezes até contraditórios. No entanto, em reação contra a tradição hegeliana e aquela induzida pelos moralistas escoceses, que confunde sociedade civil e mercado, as recentes contribuições teóricas convergem para atribuir a sociedade civil uma dimensão deliberativa envolta dos espaços públicos de debates (Eme, 1995). Ao contrário daquilo que tinha sido uma constante nas pesquisas sobre as associações no período de crescimento, a saber suas utilizações como meio de acesso ao poder eletivo, a sociedade civil é nesse caso percebida como oferecendo uma teoria auto-limitada da democratização que procuraria limitar o domínio do Estado e não a tomar o poder estatal. $\mathrm{O}$ "atual discurso da sociedade civil está precisamente centrado nas novas formas de associação coletiva que não se baseiam, em geral, em relações de classe, mas nas instituições públicas, sociais, jurídicas e associativas às quais elas estão ligadas" (Cohen e Arato, 1993, p. 41). "Os sistemas democráticos pressupõem sujeitos associados e não atomizados" e o novo modelo de sociedade civil se inscreve em " uma concepção intersubjetiva e que integra individualidade e autonomia". Esse retorno à temática da sociedade civil demostra que alguns espaços públicos são amplamente ocupados pelos poderes instituídos. Em uma sociedade dominada pelas mídias de massa, as associações que não forem resguardadas da introdução das lógicas de sistema podem, portanto, contribuir para a vitalidade de espaços públicos diversificados ${ }^{2}$ porque a evolução da sociedade não pode ser reconduzida para um processo de colonização dos mundos vividos. Daí a insistência de certos autores sobre "a posição eminente na sociedade civil" das associações "em volta das quais podem se cristalizar espaços públicos autônomos" (Habermas, 1992, p. 186). Numerosas obras têm "em comum uma atenção voltada 
para as associações voluntárias e a vida associativa enquanto principal meio para a definição de engajamentos públicos” (Eley, 1992).

Em vista disso, a conceitualização da economia pluralista contribui para a abertura do campo das possibilidades democráticas. $\mathrm{O}$ reconhecimento de que nem a economia seria reconstruída unicamente sobre o mercado, e que nem a proteção social emanaria unicamente do Estado, nos conduz a interessarmo-nos pelas influências recíprocas entre espaços públicos autônomos e esferas definidas como sociais e econômicas. Através de certos espaços intermediários que constituem as associações, pode acontecer uma extensão do domínio público incluindo uma reflexão sobre o futuro da economia e do social. As futuras elaborações da proteção social e da economia não estão desvinculadas das ações nos confins políticos não-institucionais e institucionais colocadas em prática no quadro da "relação de associações" (Offe, 1989; Cohen e Arato, 1994).

\section{Tradução Emmanuelle Girard Ferreira Nunes}

\section{Notas}

1 Período de 1945 a 1973, marcado por um desenvolvimento nunca antes visto nos países industrializados, e a respeito do qual o economista francês Jean Fourastié escreveu: ne doit on pas dire glorieuses les trente années qui on fait passer la France de la vie végétative traditionelle aux niveaux de vie et aux genres de vie contemporains? (nota da revisora).

2 Inclusive em nivel europeu, é o que mostra E. Dacheux neste trabalho.

Abstract. In Europe, the acknowlegement of the Human Rights provoked
the old social order's instability without eliminating, however, diferences
in social condition, inherited from traditional societies. With the 19th.
century emerging social questions, compatibility between citzenship and
economical development became an object of passionate debates assumed
by newly coming associations. This article aims at underlining the
significant amount of researches focusing on associations, which mark
its difference from a patterned theoretical economical hypothesis and
deductions, chosing, instead, comprehensive and historical
methodologies. The main results lead to take the notions of non profit 
and third sector as relative. The concept of solidarity became the core of the explanation of many social practices which could be tied under the generic tittle of civic associations.

Résumé. En Europe, en effet, la reconnaissance des drois de l'homme et du citoyen a déstabilisé l' ancien ordre social sans éliminer les différences de conditions héritées des sociétés traditionelles. Avec l'apparition de la question sociale, dès le dix-neuvième siècle, la compatibilité entre citoyenneté et développement économique a en conséquence fait l'objet de débats passionnés dans lesquels se sont inscrites les émergences associatives. L'objet de cette contribuition est de souligner l'existence d'un nombre significatif de recherches sur l'associationnisme qui se démarquent des perspectives hypothético-déductives propres à la théorie économique standard en ayant recours à des méthodologies plus historiques et compréhensives. Leurs principaux résultats amènent à relativiser les notions de non lucrativité et de tiers secteur. C'est plutôt le concept de solidarité qui apparaît essentiel pour expliciter des pratiques diverses qui peuvent être regroupées sous l'appellation générique d'associationisme civique.

\section{Referências bibliográficas}

ARCHAMBAULT, E. Le secteur sans but lucratif: associations et fondations en France. Paris : Economica, 1996

BARTHÉLÉMY, M. Associations: um nouvel àge de la participation? Paris : Presses de sciences, 2000.

. Les associations dans la société français: um état des lieux. Paris : Fondation Nationale des Sciences Politiques, CNRS, 1994.

BAUMOL, W. J. Microeconomics of unbalanced growth: the anatomy of the urban crisis. American Economic Review, June, 1987.

BELANGER, P. R.; LEVESQUE, B. La théorie de la régulation, du rapport salarial au rapport de consommation. Un point de vue sociologique. Cahiers de Recherche Sociologique, Université du Québec à Montreal, n. 17, 1991.

BEN NER, A.; VAN HOOMISSEN, T. Non Profit Organisations in the mixed Economy. Annals of Public and Cooperative Economy, v. 4, 1991.

BORZAGA, C. The Economies of the Third Sector in Europe: the Italian experience. Trento : Department of Economy, University of Trento, 1998. 
BORZAGA, C.; MITTONE; L. The multistakeholders versus the nonprolit organization. Trento : Universitá degli Studi di Trento, 1997. (Draft paper n. 7).

BOLLDING, K. La economia del amor y del temor. Madrid : Alianza, 1973.

BOURGELOIS, L. Solidarité. Paris : Colin, 1992.

CAILLÉ, A. Comment on écrit l'histoire du marché: réflexions critiques sur le discours historien, plus particuliérement inspirées par "Civilisation matérielle, économie et capitalisme" de Fernand Braudel. Revue du MAUSS, n. 3-4, p. 104-143, 3-4 trim.,1982; n. 5, p. 47-80, ler trim. 1983.

CHANIAL, P. L'association est-elle une politique? Revue du MAUSS, L'autre socialisme, n. 16, p. 283, 2eme sem. 2000.

COHEN, J. L.; ARATO, A. Civil society and political theory. Cambridge, Mass.: The MIT Press, 1994.

COHEN, J. L.; ARATO, A. Un nouveau modèle de société civil. Les temps modernes, n. 504, juil. 1993.

DI MAGGIO, P. J.; POWELL, W.W. The, iron cage revisited: institucional isomorphism and collective rationality in organizational fields. American Sociological Review, v. 48, apr. 1983.

DONATI, P. (A cura di). Sociologia del terzo settore. Roma : La Nueva Italia Scientifica, 1996.

DUBOIS, P. Préface. In: POLANYI, Karl. La grande transformation: aux origines politiques et economiques de notre temps. Paris : Gallimard, 1985.

ELEY, G. Nations, publics and political cultures: placing Habermas in the Nineteenth Century. In: CALHOUN, G. Habermas and the Public Sphere. Cambridge, Mass: MIT Press, 1992.

EME, B.; LAVILLE, J. L. Pour une approche pluraliste du tiers secteur. Nouvelles Pratiques Sociales, Montreal, v. 11, n. 2; v. 12, n. 1, Printemps, 1999.

EME, B.; LAVILLE, J. L. (Dir.). Cohésion sociale et emploi. Paris: Desclée de Brouwer, 1994.

ENJOLRAS, B. Associations et isomorphisme institutionnel. Revue des Études Coopératives, Mutualistes et Associatives, v. 75, n. 261, 1996.

ESPING-ANDERSEN, G. The three worlds of Welfare Capitalism. Harvard University Press, 1990.

EVERS, A. Le tiers secteur au regard d'une conception pluraliste de la protetion sociale. In: MIRE. Produir les solidarités: la part des associations. Paris: Fondation de France, 1997. 
EVERS, A. Im Intermediaren Bereich: Soziale trager und Projekte Zwischen Hanshalt. Staat un Markt. Journal fur Sozalforschung 2, 1990.

EVERS, A.; BODE, L., GRONBACHS, GRAF, A. The enterprises and organisations of the third sector: a strategic challenge for employment, national report Germany. CIRIEC. Working Group 1. Liége, 1999.

EWALD, F. L'Etat-providence. Paris: Seuil, 1986.

FOLBRE, N. De la différence des sexes en économie politique. Paris: Des Femmes, 1997.

GADREY, J. La gauche et le marché: une incompréhension plurielle. Le Monde, Paris, 10 Mars, 1999.

GIDDENS, A. Beyond left and right: the future of radical politics. Cambridge: Polity Press, 1994.

GOFFMAN, E. Les rites d'interaction. Paris : Minuit, 1974.

GUI, B. Fondemente économique du tiers secteur. Revue des Études Coopératives, Mutualistes et Associatives, n. 44-45, 4. trim. 1992 - $\mathrm{l}^{\mathrm{er}}$ trim. 1993.

HABERMAS, J. L'espace public: 30 ans après. Quaderni, n. 18, automne, 1992.

HANSMANN, H. The role of nonprofit enterprise. Yale Law Journal, n. 89, 1980.

HANTRAIS, L.; LETABLIER, M. T. La relation famille-emploi: une comparaison des modes d'ajustement en Europe. Cahiers du Centre d'Études de l'Emploi, Dossier n. 6, 1995.

JUAN, S. L'utilité sociale de l'activite associative face a la professionnalisation et a la 'marchandisation'. Sociologie du Travail, Paris, n. 41, 1999.

KLAUSEN, K. K.; SELLEP. The third sector in Scandinavia. Voluntas, v. 7, n. 2, 1996.

KRAMER, R. M. et al. Privatization in four European countries. New York : M.E. Sharpe Armonk, 1993.

LAFORRE, R. Droit d'usagers: une problematique à depasser. In: CHAUVIERE, M.; GODBOUT, J. T. Les usagers entre marché et citoyenneté. Paris : L'Harmattan, 1992.

LARRAECHEA, I.; NYSSENS, M. Les défis de l'economie populaire au Chili. Revue des Études Cooperatives, Mutualistes et Associatives, Paris, n. 49, 1994. 
LAVILLE, J. L. (Dir.). L'economie. Paris : Desclée de Brouwer, 2000.

LAVILLE, J. L. (Dir.). Les services de proximité en Europe. Paris : Desclée de Brouwer, 1992.

LAVILLE, J. L., GARDIN, L. (Dir.). Bilan economique et social d'initiatives locales de developement et d'emploi en Europe. Paris : CRIDA-LSCI, realisé pour la Commission des Communautes Europeennes, DGV, 1997.

LAVILLE, J. L.; SINSAULIEV, R. (Dir.). Sociologie de l'association. Paris: Desclée de Brouwer, 1998.

LA SERNA, C. A. La produccion democratica del bienestar: notas teoricomethologicas para su analisis. Cahiers du LAREPPS, Laboratoire de recherche sur les pratiques sociales, Université du Quebec a Montreal, n. 00.07, 2000.

LAZAR, M. La Republique a l'epreuve du social. In: SADOUN. M. (Dir.) La democratie en France. Paris : Gallimard, 2000.

LEICHSERING, K. The role of the labour market service in supporing nonstatutory children providers. Vienne : European Centre for Social Welfare Policy and Research., 1997.

LÉVESQUE, B. Democratisation de l'economie et economie sociale: un seenario radical pour de nouveaux partages. Cahiers du CRISES, Collectif de recherche sur les innovations sociales dans les entreprise et les syndicats, Universite du Quebec a Montreal, n. 9705, 1997.

LEWIS, J. Le secteur associatif dans l'economie mixte de la protection sociale. In: MIRE. Produire les solidarités: la part des associations. Paris: Fondation de France, 1997.

LIPIETZ A. L'opportunité d'une nouveau type de societé a vocation sociale. Rapport d'etape relatif à la lettre de mission du 17 septembre 1998 de Madame Aubry. Paris : Ministère de l'Emploi et de Solidarité, 2000.

LORENDAHL, B. Integrating the public sector and cooperative social economy - towards a Swedish new model. Annals of Public and Cooperative Economics, v. 68, n. 3, 1997.

MAHEU, L.; SALES, A. La recomposition du politique. Paris : L'Harmattan, 1991.

MAUCOURANT, J.; SERVET, J. M.; TIRAN, A. La modernité de Karl Polanyi, introduction generale. Paris: L'Harmattan, 1998.

MAUSS, M. Essai sur le don: form et reison de l'echange dans les societés archaiques. Année Sociologique, Paris, 1923. 
O'CONNOR, J. S. From women in the Welfare State to gendering Welfare State Regimes. Journal of the International Scociological Association, v. 44, n. 2, Summer, 1996.

OFFE, C. Bindung. Fessel. Bremse. Die Unubersichtlichkeit von Selbstbeschrankungsformel. In: HONNETH, A.; MACCARTHY, T.; OFFE, C.; WELLMER, A. Zwischenbertrachtungen. Francfort, 1989.

ORTIZ, H.; MUNOS, L. (Ed.). Globalizacion de la solidaridade: un reto para todos. Lima : Grupo Internacional Economia Solidaria, 1998.

ORTMANN, A.; SCHLESINGER, M. Trust: refute and the role of Non-Profit Enterprise. Voluntas, 8-2, 1997.

PATEMAN, C. The patriarchal Welfare State. In: GUTMANN, A. (Ed). Democracy and the Welfare State. Princeton : Princeton University Press, 1988.

PERROUX, F. Economie et societé: contrainte-echange-don. Paris : Presses Universitaires de France, 1960.

PESTOFF, V. A. Beyond the market and state: social enterprises and civil democracy in a welfare society. Ashgate : Aldershot, 1998.

PESTOFF, V. A. Social enterprises and civil democracy in Sweden: enriching work environment and empowering citizens as co-producers. Stockholm: School of Busines, 1997.

PESTOFF, V. A. Third Sector and co-operative : an alternative to privatization. Journal of Consumer Policy, Stockholm, v. 15, 1992.

POLANYI, K. La grande transformation: aux origines politiques et economiques de notre temps. Paris : Gallimard, 1983.

RANCI, C. Doni serviza reciprocita : la persistenza dell'altruismo sociale nei sistemi complessi. Rassegna Italiana de Sociologia, v. 31, n. 3, juin/ sep. 1990.

RAZETO MIGLIARO, L. Economie de solidaridad y mercado democrático : libro tercero - fundamentos de una teoria economica compensiva. Programa de Economia del Trabajo. Santiago du Chili, 1988.

ROUSTANG, G. L'emploi: un choix de société. Paris : Syros, 1987.

ROUSTANG, G.; LAVILLE, J. L.; EME, B.; MOTHE, D.; PERRET, B. Vers un nouveau contrat social. Paris : Desclée de Brouwer, 1996.

SAJARDO-MORENO, A. Economie social et services sociaux en Espagne. Revue des Études Cooperatives, Mutualistes et Associatives (RECMA), v. 261, n. 59, $3^{\text {eme }}$ trim. 1996. 
SALAMON, L. M. The nonprofit sector and Government: the American experience in theory and practice. In: ANHEIER, H.; SEIBEL, W. (Eds.). The third sector: comparative studies of Nonprofit Organizations. Walter de Gruyter, 1990.

SALAMON, L. M.; ANHEIER H. Social origins of civil society: explaininig the nonprofit sector cross-nationally. Baltimore : The Johns Hopkins University, Institute for Policy Studies, 1996.

SALAMON, L. M.; ANHEIER, H. The civil society sector: a new Global force. Society. v. 34, n. 4, Mai 1997.

SAUVIAT, C. L'accueil ou la garde d'enfants: des marchés de services façonnés par les contextes nationaux. Suède. États-Unis. France. Paris : IRES, 1996.

STROBEL, P. Service public, fin de siècle. In: GREMION, C. (Dir.). Modernisation des services publics. Paris : Commissariat General du Plan, Ministére de la Recherche, 1995.

TITTMUS, R. M. Social policy. Londres : Allen \& Unwin, 1974.

VERLEY, P. Economie de marche: une construction historique. Alternatives Economiques, n. 166, jan. 1999.

VIENNEY, C. L'economie sociale. Paris : Reperes, La Découverte, 1994.

. Socio-economie des organisations cooperatives, tome 2: analyse comparee des cooperatives fonctionnant dans des systemes socioeconomiques differents. Paris: Cooperative d'information et d'edition mutualiste, 1982.

VINCENT, G. Solidaires de qui...? Réflexions épistémologiques. In: MISSION RECHERCHE - MIRE. Rencontres et Recherches avec la collaboratio de la Fondation de France. Produire les solidarités: la part des associations. Paris, 1997.

VIVET, D.; THIRY, B. Champ de l'étude, importance quantitative et acceptions nationales. In: Les entreprises et organisation du troisieme systeme. Un enjeu strategique pour l'emploi. Action pilote "Troisième système et emploi" de la Commission européenne. Liège CIRIEC, 1997.

YOUNG, D. R. Entrepreneurship and the behavior of Nonprofit Organizations: elements of a Theory. In: WHITE, M. (Ed.). Nonprofit firms in a threesector Economy. Washington D.C. : Urban Institute, 1981. 